\title{
EFFECT OF HIGH-ENERGY PROTONS ON 4H-SiC RADIATION DETECTORS
}

\author{
V. Kažukauskas a ${ }^{\text {, R. Jasiulionis }}{ }^{\mathrm{b}}$, V. Kalendra ${ }^{\mathrm{a}}$, and J.-V. Vaitkus ${ }^{\mathrm{a}}$ \\ ${ }^{a}$ Semiconductor Physics Department and Institute of Materials Science and Applied Research, Vilnius University, \\ Sauletekio 9, LT-10222 Vilnius, Lithuania \\ E-mail: vaidotas.kazukauskas@ff.vu.lt \\ ${ }^{\mathrm{b}}$ Institute of Physics, Savanoriu 231, LT-02300 Vilnius, Lithuania
}

Received 30 June 2005

\begin{abstract}
We present investigation of high energy radiation detectors based on $4 \mathrm{H}-\mathrm{SiC}$ as influenced by irradiation with $24 \mathrm{GeV}$ proton doses of up to $10^{16} \mathrm{~cm}^{-2}$. SiC detectors have been produced from $n$-type $4 \mathrm{H}$-SiC epilayers grown on the top of the $n^{+}$-type substrate. They were supplied with a nickel ohmic contact on the back surface and a gold Schottky contact on the top. Activities and numbers of ${ }^{7} \mathrm{Be}$ and ${ }^{22} \mathrm{Na}$ atoms produced in $\mathrm{SiC}$ detectors after the irradiation were measured experimentally. Activities of other radionuclides were calculated on the basis of this data. Activities of ${ }^{7} \mathrm{Be}$ and ${ }^{22} \mathrm{Na}$ were proportional to the total irradiation dose and ranged from 1.3 to $890 \mathrm{~Bq}$ and from 1.9 to $950 \mathrm{~Bq}$, respectively. In the samples irradiated with $1 \cdot 10^{13}$ and $1 \cdot 10^{16}$ protons $/ \mathrm{cm}^{2} 390$ days after the irradiation the number of radiated electrons with different energies was from 1.0 to 600 per second, respectively. Contact properties of the devices were investigated by means of the current-voltage $(I-V)$ characteristics. It was found that proton irradiation with the highest doses leads to the significant changes of the contact properties. Namely, the contact potential barrier grows from about $0.7-0.75 \mathrm{eV}$ in the pristine and less irradiated samples up to about $0.84 \mathrm{eV}$ in the detectors irradiated by highest doses. Moreover, rectifying behaviour of the Schottky contacts becomes much less expressed upon irradiation, tending to become nearly symmetrical. The observed behaviour probably can be explained by the appearance of the irradiation-induced inhomogeneous regions of detectors that limits the applicability of classical contact theory.
\end{abstract}

Keywords: 4H-SiC, high-energy radiation detectors, proton irradiation, radionuclides

PACS: 61.80.-x, 72.80.Jc, 85.30.De

\section{Introduction}

$\mathrm{SiC}$ is an emerging semiconductor material that is undergoing rapid development for use in hightemperature, high power density applications [1]. $6 \mathrm{H}-\mathrm{SiC}$ and $4 \mathrm{H}-\mathrm{SiC}$ semiconductor compounds have a wide bandgap $(>3 \mathrm{eV})$, resulting in low equilibrium carrier concentration, low leakage current, and high specific resistivity, which is up to $10^{11} \Omega \cdot \mathrm{cm}$ at room temperature. Therefore the material has a high breakdown field of about $3 \cdot 10^{6} \mathrm{~V} / \mathrm{cm}$. $4 \mathrm{H}-\mathrm{SiC}$ is more preferable because of its higher electron mobility of about $800 \mathrm{~cm}^{2} /(\mathrm{V} \cdot \mathrm{s})$ as opposed to $370 \mathrm{~cm}^{2} /(\mathrm{V} \cdot \mathrm{s})$ in $6 \mathrm{H}-\mathrm{SiC}$. Namely, high breakdown field enables one to achieve high drift electron velocities and, hence, high device frequencies. Because of that and of the high thermal conductivity the $\mathrm{SiC}$ detectors were shown to be able to operate at temperatures up to $700^{\circ} \mathrm{C}$. Moreover, $\mathrm{SiC}$ electronics offer unique advantages for nuclear power applications. The response of SiC Schot- tky diodes was demonstrated to be linear with thermal neutron fluence rate and gamma dose to better than 5\% with a precision of better than $0.6 \%$ over nine orders of magnitude in fluence rate. Self-annealing operation may be possible -i. e., devices could be operated at elevated temperatures where radiation damage will not accumulate $[2,3]$.

On the other hand, SiC-based device yield and efficiency are significantly limited by relatively high defect density in the material. Though during recent years the technological advances in large-scale single crystal growth have resulted in high-quality commercial $50 \mathrm{~mm}$ and $75 \mathrm{~mm}$ diameter $\mathrm{SiC}$ wafers with a density of micro-pipes down to a few tens per square centimeter, despite this evident progress in SiC crystal growth, uncontrollable point defects and impurities persist in the material at the level of $10^{15}-10^{17} \mathrm{~cm}^{-3}$ (e. g., $[4,5])$. Moreover, usually many different levels with quite different parameters are reported by 
different investigators even in the samples produced and processed by the similar technological process (see, e.g., discussion in Ref. [4]). Apart from point defects, dislocation density is also still high in $\mathrm{SiC}$ reaching values of some $10^{6} \mathrm{~cm}^{-2}$ (e.g., [6]). Additional complications arise when exploring the spatial distribution of recombination and transport parameters across the large-size $\mathrm{SiC}$ wafers. Inhomogeneity of the defect distribution can be very dramatic and requires utilization of spatially resolved non-contact and nondestructive scanning (mapping) techniques. A number of mapping techniques were used to prove defect profiling in SiC wafers, including photoluminescence $[7,8]$, spectroscopic optical transmission [9], capacitive contactless resistivity [10], Raman imaging [11], and thermally stimulated luminescence $[12,8]$. Electron and hole traps in the forbidden energy gap usually deteriorate device effectiveness due to the trapping of free charge carriers generated by irradiation. Moreover, irradiation by high energy particles can introduce significant inhomogeneities, the effect of which reflects itself also on the electrical characteristics of the devices. Parameters, characterizing radiation detectors based on the Schottky junction.

Though in highly doped material the effect of some defects diminishes due to their screening by charge carriers, if the defect density is high and / or their distribution is inhomogeneous, they still can significantly modify properties of the material itself and of the devices on its basis (e. g., [13]). As different material defects can be effectively introduced and / or modified by high energy irradiation or implantation (e. g., [14-16]), it is an important task to investigate an impact of different irradiation types and doses on the device properties. This would enable one to predict and model material and device parameters as required for material and device engineering. Therefore in this paper we present investigation of the effect of high-energy proton irradiation on the properties of $4 \mathrm{H}-\mathrm{SiC}$ based Schottky diodes radiation detectors.

\section{Samples and experiment}

We investigated radiation detectors fabricated from $n$-type $4 \mathrm{H}-\mathrm{SiC}$ epilayers grown at the IKZ (Institut für Kristallzüchtung, Berlin) on the top of the $n^{+}$-type substrate from the CREE Company. $\mathrm{C} / \mathrm{Si}$ ratio during the growth was maintained to be 1.5 , the growth temperature was $1550{ }^{\circ} \mathrm{C}$, the rate was $9 \mu \mathrm{m} / \mathrm{h}$, and the pressure of $\mathrm{N}_{2}$ was $(6.4-9.2) \cdot 10^{-4}$ mbar. The thickness of the layers was about $30 \mu \mathrm{m}$. The doping concentration of the layers so produced was $(0.5-1) \cdot 10^{14} \mathrm{~cm}^{-3}$. The $\mathrm{SiC}$ detectors were made in a standard parallel plate configuration by depositing an approximately $150 \mathrm{~nm}$ thick gold Schottky contact on the top surface and an annealed nickel ohmic contact on the bottom surface. The top contacts had central semitransparent optical windows of a very thin gold layer, approximately $5 \mathrm{~nm}$ thick. To minimise surface leakage effects [17], a guard ring was used to surround the top contact, coupled with silicon nitride passivation of remaining free $\mathrm{SiC}$ surfaces. In these detectors the charge collection efficiency while irradiating the samples with $\alpha$-particles and $\gamma$-rays was found to be up to nearly $100 \%$ at the reverse bias voltages up to $600 \mathrm{~V}$ [18]. Nevertheless, other investigators report significant changes of material properties upon irradition by, e. g., pions [19].

We have investigated the effect of irradiation of such detectors by different doses of $24 \mathrm{GeV}$ protons ranging from $1 \cdot 10^{13} \mathrm{~cm}^{-2}$ up to $1 \cdot 10^{16} \mathrm{~cm}^{-2}$. The irradiation was performed at the facilities of CERN. For the estimation of the number of radionuclides and isotopes in detectors, we have applied measurement and evaluation methods that are usually applied in the investigation of cosmogenic radionuclides produced in the atmosphere in cosmic ray nuclear reactions with oxygen, nitrogen, and argon nuclei [20].

The contact properties of the non-irradiated and irradiated detectors were compared by investigating their $I-V$ characteristics. The obtained experimental dependences were fitted using the Schottky barrier model. The model foresees the following $I-V$ dependences:

$$
I(U)=I_{\mathrm{s}}\left[\exp \left(\frac{e\left(U-I R_{s}\right)}{n k T}\right)-1\right],
$$

here $I_{\mathrm{S}}$ is the saturation current, $U$ is applied voltage, $R_{s}$ is a serial resistance of the sample volume, and $n$ is the ideality factor, which describes deviations from the ideal thermionic emission model. The saturation current density $j_{\mathrm{s}}$ is given by

$$
j_{\mathrm{s}}=A^{*} T^{2} \exp \left(-\frac{e \Phi_{\mathrm{B}}}{k T}\right),
$$

here $\Phi_{\mathrm{B}}$ is the contact potential barrier height, and $A^{*}$ is the Richardson constant:

$$
A^{*} T=C N_{\mathrm{c}}
$$

here $C$ is a proportionality constant, $N_{\mathrm{c}}$ is the effective density of states in the conduction band:

$$
N_{\mathrm{c}}=2\left(\frac{2 \pi m_{n} k T}{h^{2}}\right)^{3 / 2}
$$




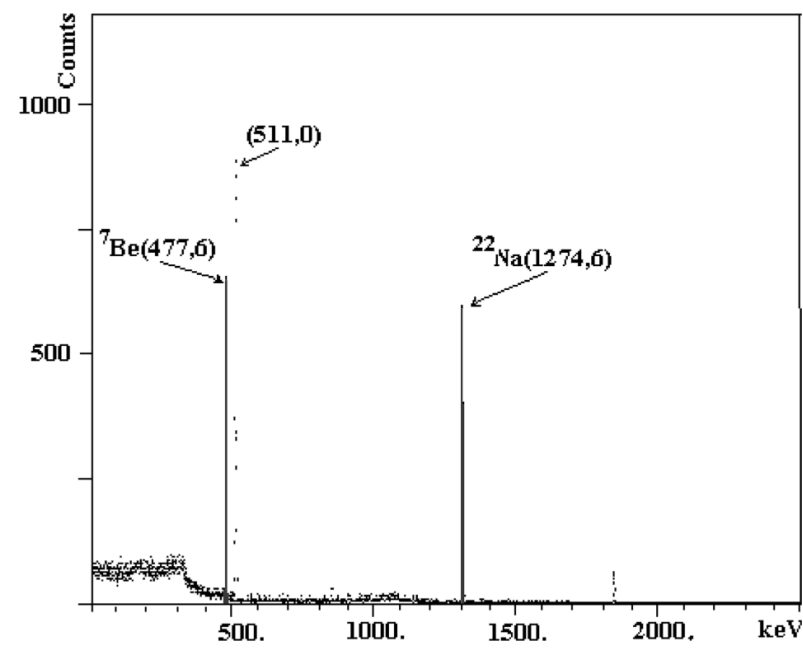

Fig. 1. Gamma spectrum of the $\mathrm{SiC}$ sample irradiated by $24 \mathrm{GeV}$ protons. The spectrum was measured by a high-purity germanium spectrometer 240 days after the irradiation.

$$
=3.25 \cdot 10^{15} \cdot T^{3 / 2}\left(\mathrm{~cm}^{-3}\right) \quad(4 \mathrm{H}-\mathrm{SiC}) \text {. }
$$

The vacuum value of the Richardson constant is $120 \mathrm{~A} \cdot \mathrm{cm}^{-2} \cdot \mathrm{K}^{-2}$. The effective mass of conductivity electron for $4 \mathrm{H}-\mathrm{SiC}$ is $0.36 \mathrm{~m}_{0}$.

\section{Results and discussion}

\subsection{Irradition-induced changes of the elemental composition of material}

It is known that by irradiation of materials with charged high energy particles (in our case $24 \mathrm{GeV}$ protons) about $10 \%$ of their energy is used for the production of radionuclides in nuclear spallation reactions with target nucleons (in our case SiC). Using a low background, high resolution pure germanium gamma spectrometer, ${ }^{7} \mathrm{Be}$ and ${ }^{22} \mathrm{Na}$ radiation was registered in the irradiated detectors (Fig. 1). Gamma spectra measurements were carried out 240 days after the irradiation. The experiments were repeated again after 150 more days. Activities of ${ }^{7} \mathrm{Be}$ and ${ }^{22} \mathrm{Na}$ in the irradiated samples were calculated on the basis of the ground estimation of their decay within 240 days. The evaluations were done for the three characteristic time moments: that of the irradiation itself, 240 days later, and 390 days later (03.11.2003, 01.07.2004, and 01.12.2004, respectively). Results are presented in Figs. 2 and 3.

Results of the separation of gamma spectrum and calculation of ${ }^{7} \mathrm{Be}$ and ${ }^{22} \mathrm{Na}$ activity 240 days after the irradiation, as well as the evaluation of the numbers of ${ }^{7} \mathrm{Be}$ and ${ }^{22} \mathrm{Na}$ atoms in the samples after the irradiation are presented in Table 1 .

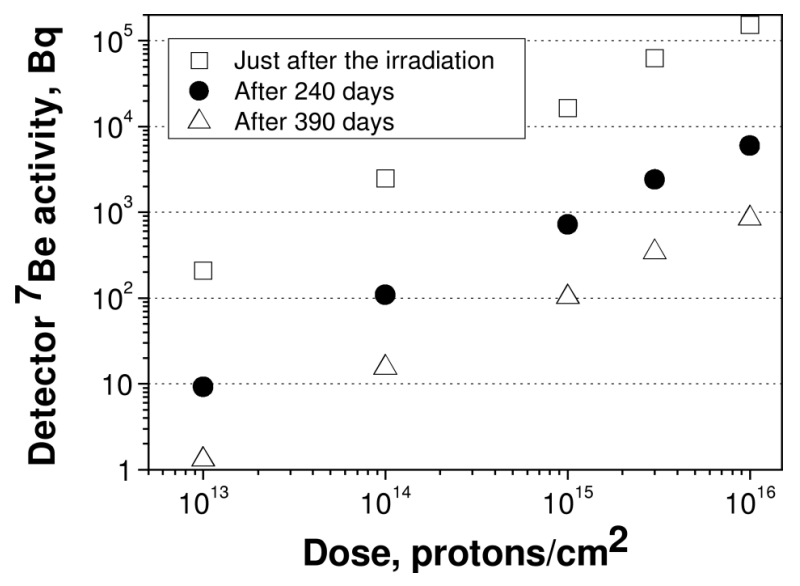

Fig. 2. Dependence of the ${ }^{7} \mathrm{Be}$ activity in the samples on the irradiation dose at three characteristic time moments: that of the irradiation itself, 240 days, and 390 days after the irradiation.

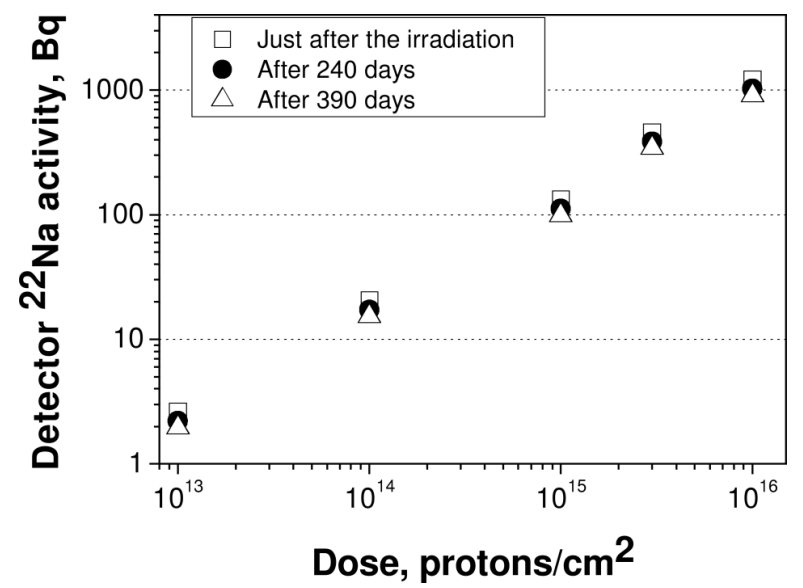

Fig. 3. Dependence of the ${ }^{22} \mathrm{Na}$ activity in the samples on the irradiation dose at three characteristic time moments: that of the irradiation itself, 240 days, and 390 days after the irradiation.

Experiments with the samples irradiated with similar doses were repeated several times, and the results were coinciding within the ranges of experimental errors, confirming statistical reliability of the data. Therefore the presented experimentally estimated activities of ${ }^{7} \mathrm{Be}$ and ${ }^{22} \mathrm{Na}$ atoms produced in nuclear spallation reaction were used to calculate the numbers of their atoms in $\mathrm{SiC}$ detectors directly after the irradiation (the decay constants are known with high precision). ${ }^{7} \mathrm{Be}$ and ${ }^{22} \mathrm{Na}$ activities in the samples are very similar. This qualitatively confirms that ${ }^{7} \mathrm{Be}$ was produced in proton interaction with carbon nuclei and ${ }^{22} \mathrm{Na}$ - with silicon nuclei.

In nuclear spallation reactions of $24 \mathrm{GeV}$ protons with a natural composite of ${ }^{12} \mathrm{C}(98.9 \%)$ and ${ }^{13} \mathrm{C}$ (1.1\%) carbon isotopes $\mathrm{B}, \mathrm{Be}, \mathrm{Li}, \mathrm{He}$, and $\mathrm{H}$ isotopes and radionuclides are produced. Meanwhile, during the reaction of protons with a natural composite of ${ }^{28} \mathrm{Si}$ 
Table 1. Results of the separation of gamma spectrum, calculation of ${ }^{7} \mathrm{Be}$ and ${ }^{22} \mathrm{Na}$ activity 240 days after the irradiation, and evaluation of the numbers of ${ }^{7} \mathrm{Be}$ and ${ }^{22} \mathrm{Na}$ atoms after the irradiation of $\mathrm{SiC}$ samples by different proton doses.

\begin{tabular}{|c|c|c|c|c|c|}
\hline \multirow[t]{2}{*}{$\begin{array}{l}\text { Detector } \\
\text { No }\end{array}$} & \multirow{2}{*}{$\begin{array}{c}\text { Irradiation dose } \\
\text { (24 GeV protons), } \\
\mathrm{cm}^{-2}\end{array}$} & \multicolumn{2}{|c|}{$\begin{array}{l}\text { Activity in gamma spectra } \\
240 \text { days after irradiation, } \mathrm{Bq}\end{array}$} & \multicolumn{2}{|c|}{$\begin{array}{l}\text { Number of atoms } \\
\text { after the irradiation }\end{array}$} \\
\hline & & ${ }^{7} \mathrm{Be}$ & ${ }^{22} \mathrm{Na}$ & ${ }^{7} \mathrm{Be}$ & ${ }^{22} \mathrm{Na}$ \\
\hline 1 & $1 \cdot 10^{13}$ & 9.2 & 2.2 & $1.4 \cdot 10^{9}$ & $3.1 \cdot 10^{8}$ \\
\hline 2 & $1 \cdot 10^{14}$ & 11 & 17 & $1.6 \cdot 10^{10}$ & $2.4 \cdot 10^{9}$ \\
\hline 3 & $1 \cdot 10^{15}$ & $7.3 \cdot 10^{2}$ & $1.1 \cdot 10^{2}$ & $1.1 \cdot 10^{11}$ & $1.5 \cdot 10^{10}$ \\
\hline 4 & $3 \cdot 10^{15}$ & $2.4 \cdot 10^{3}$ & $3.8 \cdot 10^{2}$ & $4.1 \cdot 10^{11}$ & $5.3 \cdot 10^{10}$ \\
\hline 5 & $1 \cdot 10^{16}$ & $5.8 \cdot 10^{3}$ & $1.0 \cdot 10^{3}$ & $1.0 \cdot 10^{12}$ & $1.4 \cdot 10^{11}$ \\
\hline
\end{tabular}

(92.3\%), ${ }^{29} \mathrm{Si}(4.7 \%)$, and ${ }^{30} \mathrm{Si}(3.0 \%)$ silicon isotopes $\mathrm{Al}, \mathrm{Mg}, \mathrm{Na}, \mathrm{Ne}, \mathrm{F}, \mathrm{O}$, and $\mathrm{N}$ isotopes and radionuclides are produced. The amounts of these reaction products can be evaluated by knowing the amounts of ${ }^{7} \mathrm{Be}$ and ${ }^{22} \mathrm{Na}$ directly after the irradiation and comparing the cross-sections of the corresponding reaction products.

The cross-section of the formation of radionuclides in nuclear spallation reactions of nucleons in a large range of energy is described by an empirical formula based on a large number of experimental results [21, 22]:

$$
\begin{aligned}
\sigma= & \sigma_{0} f(A) f(E) \\
& \times \exp \left[-P \Delta A_{e}-R\left(Z-S A+T A^{2}\right)^{\gamma}\right] \Omega \eta \xi .
\end{aligned}
$$

In Eq. (5) $\sigma_{0}$ is a normalization factor. The factors $f(A)$ and $f(E)$ apply to products from heavy targets (with atomic numbers $Z_{t}>30$ ) when $\Delta A$ is large, as for fission, fragmentation, and evaporation of light product nuclei. The factor $\exp (-P \Delta A)$ describes the diminution of cross-sections as the difference of target and product mass, $\Delta A=A_{t}-A$, increases. The factor $\exp \left[-R\left(Z-S A+T A^{2}\right)^{\gamma}\right]$, with $\gamma \approx 3 / 2$, describes the distribution of cross-sections for the production of various isotopes of an element of atomic number $Z$. The Gaussian-like distribution is related to the statistical nature of the nuclear evaporation process. The width of the distribution of cross-section is represented by the parameter $R=1.6$ for $E \geq 1250 \mathrm{MeV}$. The parameter $S=0.52-0.08\left[A_{t} /\left(Z_{t}-2\right)\right]$ describes the location of the peaks of the distribution curves.

The cross-sections of the production of radionuclides and isotopes in nuclear reactions of $24 \mathrm{GeV}$ protons with the natural composite of carbon isotopes were calculated from Eq. (5). We have calculated the ratios of the cross-section of ${ }^{7} \mathrm{Be}$ production and that of the production of radionuclides and isotopes lighter than $\mathrm{C}$ atoms. It was assumed that the short-living radionuclides had fully decayed, except tritium. The number of their $\beta^{-}$and $\beta^{+}$decay products and the number of the respective isotopes were summed. Results of the calculation obtained by multiplying the numbers of ${ }^{7} \mathrm{Be}$ atoms after the irradiation (Table 1) and the ratios of the cross-sections of production of the radionuclides and isotopes are given in Table 2.

In a similar way, on the basis of Eq. (5), the crosssections of production of the radionuclides and isotopes more heavy than $\mathrm{C}$ that had been produced in nuclear reactions of $24 \mathrm{GeV}$ protons with the natural composite of silicon isotopes were calculated. Results of calculations were obtained by multiplying the numbers of ${ }^{22} \mathrm{Na}$ atoms after the irradiation (Table 1) and the ratios of the cross-sections of production of the radionuclides and isotopes, and by adding the numbers of $\beta^{-}$and $\beta^{+}$ decay products. They are presented in Table 3 .

The numbers of ${ }^{7} \mathrm{Be}$ decay product, i.e., ${ }^{7} \mathrm{Li}$, and ${ }^{22} \mathrm{Na}$ decay product $-{ }^{22} \mathrm{Ne}$, produced within 390 days after the irradiation, were added to the numbers of their isotopes produced by different channels of reactions (Tables 2 and 3).

The calculations based on Eq. (5) enable estimation of the number of long-lived radionuclides in the samples as well as their activity 390 days after the irradiation, too. The radionuclides produced in proton reactions with carbon are tritium ${ }^{3} \mathrm{H}\left(t_{1 / 2}=12.36\right.$ years $)$ and ${ }^{10} \mathrm{Be}\left(t_{1 / 2}=1.6 \cdot 10^{6}\right.$ years $)$. Meanwhile in proton reactions with silicon the ${ }^{14} \mathrm{C}\left(t_{1 / 2}=5730\right.$ years $)$ and ${ }^{26} \mathrm{Al}\left(t_{1 / 2}=7.16 \cdot 10^{5}\right.$ years $)$ are produced. Activities of ${ }^{7} \mathrm{Be}$ and ${ }^{22} \mathrm{Na}$ evaluated directly by measuring gamma spectra and the estimated activities of the longlived radionuclides 390 days after the irradiation are given in Table 4.

Radionuclide decay is accompanied by the radiation of high energy electrons, the effect of which reflects itself also on the electrical characteristics of the devices. ${ }^{3} \mathrm{H},{ }^{10} \mathrm{Be}$, and ${ }^{14} \mathrm{C}$ undergo $\beta^{-}$decay. Activity of ${ }^{10} \mathrm{Be}$ is low and the number of radiated electrons is small even at higher irradiation doses. Boundary energy of the electrons radiated by ${ }^{3} \mathrm{H}$ is $5.7 \mathrm{keV}$, and that of the 
Table 2. Numbers of light isotopes in $\mathrm{SiC}$ detectors after the irradiation by $24 \mathrm{GeV}$ protons with different doses.

\begin{tabular}{ccccccccccc}
\hline No & Dose, $\mathrm{cm}^{-2}$ & ${ }^{11} \mathrm{~B}$ & ${ }^{10} \mathrm{~B}$ & ${ }^{9} \mathrm{Be}$ & ${ }^{7} \mathrm{Li}$ & ${ }^{6} \mathrm{Li}$ & ${ }^{4} \mathrm{He}$ & ${ }^{3} \mathrm{He}$ & ${ }^{2} \mathrm{H}$ & ${ }^{1} \mathrm{H}$ \\
\hline 1. & $1 \cdot 10^{13}$ & $1.0 \cdot 10^{8}$ & $1.5 \cdot 10^{8}$ & $1.5 \cdot 10^{8}$ & $4.9 \cdot 10^{8}$ & $7.7 \cdot 10^{8}$ & $4.9 \cdot 10^{9}$ & $9.7 \cdot 10^{8}$ & $8.9 \cdot 10^{8}$ & $6.3 \cdot 10^{8}$ \\
2. & $1 \cdot 10^{14}$ & $1.2 \cdot 10^{9}$ & $1.8 \cdot 10^{9}$ & $1.8 \cdot 10^{9}$ & $3.5 \cdot 10^{9}$ & $9.0 \cdot 10^{9}$ & $5.8 \cdot 10^{10}$ & $1.1 \cdot 10^{10}$ & $1.1 \cdot 10^{10}$ & $7.4 \cdot 10^{9}$ \\
3. & $1 \cdot 10^{15}$ & $8.1 \cdot 10^{9}$ & $1.2 \cdot 10^{10}$ & $1.2 \cdot 10^{10}$ & $2.3 \cdot 10^{10}$ & $6.0 \cdot 10^{10}$ & $3.8 \cdot 10^{11}$ & $7.6 \cdot 10^{10}$ & $7.0 \cdot 10^{10}$ & $5.0 \cdot 10^{10}$ \\
4. & $3 \cdot 10^{15}$ & $3.1 \cdot 10^{10}$ & $4.5 \cdot 10^{10}$ & $4.5 \cdot 10^{10}$ & $5.1 \cdot 10^{10}$ & $2.3 \cdot 10^{11}$ & $1.5 \cdot 10^{12}$ & $2.9 \cdot 10^{11}$ & $2.7 \cdot 10^{11}$ & $1.9 \cdot 10^{11}$ \\
5. & $1 \cdot 10^{16}$ & $7.5 \cdot 10^{10}$ & $1.1 \cdot 10^{11}$ & $1.1 \cdot 10^{11}$ & $2.3 \cdot 10^{11}$ & $5.6 \cdot 10^{11}$ & $3.6 \cdot 10^{12}$ & $7.1 \cdot 10^{11}$ & $6.5 \cdot 10^{11}$ & $4.6 \cdot 10^{11}$ \\
\hline
\end{tabular}

Table 3. Numbers of heavy isotopes in $\mathrm{SiC}$ detectors after the irradiation by $24 \mathrm{GeV}$ protons with different doses.

\begin{tabular}{cccccccccc}
\hline No. & Dose, $\mathrm{cm}^{-2}$ & ${ }^{28} \mathrm{Si}$ & ${ }^{27} \mathrm{Al}$ & ${ }^{26} \mathrm{Mg}$ & ${ }^{25} \mathrm{Mg}$ & ${ }^{24} \mathrm{Mg}$ & ${ }^{23} \mathrm{Na}$ & ${ }^{22} \mathrm{Ne}$ & ${ }^{21} \mathrm{Ne}$ \\
\hline 1. & $1 \cdot 10^{13}$ & $1.6 \cdot 10^{6}$ & $1.7 \cdot 10^{7}$ & $2.6 \cdot 10^{6}$ & $1.3 \cdot 10^{10}$ & $4.3 \cdot 10^{9}$ & $1.2 \cdot 10^{9}$ & $6.6 \cdot 10^{6}$ & $1.6 \cdot 10^{9}$ \\
2. & $1 \cdot 10^{14}$ & $1.3 \cdot 10^{7}$ & $1.3 \cdot 10^{8}$ & $2.1 \cdot 10^{7}$ & $9.7 \cdot 10^{10}$ & $3.4 \cdot 10^{10}$ & $1.0 \cdot 10^{10}$ & $5.2 \cdot 10^{7}$ & $1.3 \cdot 10^{10}$ \\
3. & $1 \cdot 10^{15}$ & $8.1 \cdot 10^{7}$ & $8.4 \cdot 10^{8}$ & $1.3 \cdot 10^{8}$ & $6.6 \cdot 10^{11}$ & $2.7 \cdot 10^{11}$ & $6.4 \cdot 10^{10}$ & $2.5 \cdot 10^{8}$ & $8.2 \cdot 10^{10}$ \\
4. & $3 \cdot 10^{15}$ & $2.8 \cdot 10^{8}$ & $2.9 \cdot 10^{9}$ & $4.5 \cdot 10^{8}$ & $2.2 \cdot 10^{12}$ & $7.6 \cdot 10^{11}$ & $2.1 \cdot 10^{11}$ & $1.2 \cdot 10^{9}$ & $2.8 \cdot 10^{11}$ \\
5. & $1 \cdot 10^{16}$ & $7.5 \cdot 10^{8}$ & $7.8 \cdot 10^{9}$ & $1.1 \cdot 10^{9}$ & $5.8 \cdot 10^{12}$ & $1.9 \cdot 10^{12}$ & $5.6 \cdot 10^{11}$ & $2.9 \cdot 10^{9}$ & $7.5 \cdot 10^{11}$ \\
\hline
\end{tabular}

\begin{tabular}{ccccccc}
\hline${ }^{20} \mathrm{Ne}$ & ${ }^{19} \mathrm{~F}$ & ${ }^{18} \mathrm{O}$ & ${ }^{17} \mathrm{O}$ & ${ }^{16} \mathrm{O}$ & ${ }^{15} \mathrm{~N}$ & ${ }^{14} \mathrm{~N}$ \\
\hline $6.6 \cdot 10^{9}$ & $2.1 \cdot 10^{9}$ & $5.9 \cdot 10^{8}$ & $2.8 \cdot 10^{9}$ & $8.2 \cdot 10^{8}$ & $3.5 \cdot 10^{9}$ & $1.0 \cdot 10^{10}$ \\
$5.1 \cdot 10^{10}$ & $1.7 \cdot 10^{10}$ & $4.5 \cdot 10^{9}$ & $2.2 \cdot 10^{10}$ & $6.4 \cdot 10^{9}$ & $2.8 \cdot 10^{10}$ & $8.0 \cdot 10^{10}$ \\
$3.4 \cdot 10^{11}$ & $9.8 \cdot 10^{10}$ & $2.9 \cdot 10^{10}$ & $1.4 \cdot 10^{11}$ & $4.1 \cdot 10^{10}$ & $1.8 \cdot 10^{11}$ & $5.1 \cdot 10^{11}$ \\
$1.1 \cdot 10^{12}$ & $3.7 \cdot 10^{11}$ & $1.0 \cdot 10^{11}$ & $4.9 \cdot 10^{11}$ & $1.4 \cdot 10^{11}$ & $6.2 \cdot 10^{11}$ & $1.8 \cdot 10^{12}$ \\
$3.1 \cdot 10^{12}$ & $9.8 \cdot 10^{11}$ & $2.7 \cdot 10^{11}$ & $1.3 \cdot 10^{12}$ & $3.8 \cdot 10^{11}$ & $1.6 \cdot 10^{12}$ & $4.7 \cdot 10^{12}$ \\
\hline
\end{tabular}

Table 4. Activities of the long-lived radionuclides 390 days after the irradiation.

\begin{tabular}{cccccccc}
\hline No & Dose, $\mathrm{cm}^{-2}$ & ${ }^{3} \mathrm{H}, \mathrm{Bq}$ & ${ }^{7} \mathrm{Be}, \mathrm{Bq}$ & ${ }^{10} \mathrm{Be}, \mathrm{Bq}$ & ${ }^{14} \mathrm{C}, \mathrm{Bq}$ & ${ }^{22} \mathrm{Na}, \mathrm{Bq}$ & $26 \mathrm{Al}, \mathrm{Bq}$ \\
\hline 1. & $1 \cdot 10^{13}$ & 1.8 & 1.3 & $6.7 \cdot 10^{-8}$ & $3.8 \cdot 10^{-2}$ & 1.9 & $4.0 \cdot 10^{-6}$ \\
2. & $1 \cdot 10^{14}$ & 22 & 15 & $7.9 \cdot 10^{-7}$ & 0.3 & 16 & $3.2 \cdot 10^{-5}$ \\
3. & $1 \cdot 10^{15}$ & $1.4 \cdot 10^{2}$ & $1.1 \cdot 10^{2}$ & $5.2 \cdot 10^{-6}$ & 1.9 & 10 & $2.1 \cdot 10^{-4}$ \\
4. & $3 \cdot 10^{15}$ & $5.5 \cdot 10^{2}$ & $3.4 \cdot 10^{2}$ & $1.8 \cdot 10^{-5}$ & 6.7 & $3.5 \cdot 10^{2}$ & $7.0 \cdot 10^{-4}$ \\
5. & $1 \cdot 10^{16}$ & $1.3 \cdot 10^{3}$ & $8.5 \cdot 10^{2}$ & $4.3 \cdot 10^{-5}$ & 18 & $9.1 \cdot 10^{2}$ & $1.8 \cdot 10^{-3}$ \\
\hline
\end{tabular}

electrons radiated by ${ }^{14} \mathrm{C}$ is $49 \mathrm{keV}$. 390 days after the irradiation we still could count the number of electrons with different energies radiated by these radionuclides ranging from 0.6 to 400 per second - in the samples irradiated with $1 \cdot 10^{13}$ and $1 \cdot 10^{16}$ protons $/ \mathrm{cm}^{2}$, respectively.

Radionuclides ${ }^{7} \mathrm{Be},{ }^{22} \mathrm{Na}$, and ${ }^{26} \mathrm{Al}$ undergo decay which includes electron capture. Their decay is followed by radiation of the conversion and Auger electrons: $3.9 \cdot 10^{-8}, 0.19$, and 0.45 electrons for one decay, respectively. A tangible contribution in the total sum of electrons is given only by electrons radiated by ${ }^{22} \mathrm{Na}$. It ranges from 0.4 to 200 electrons per second in the samples irradiated with $1 \cdot 10^{13}$ and $1 \cdot 10^{16}$ protons $/ \mathrm{cm}^{2}$, respectively.

In the samples irradiated with $1 \cdot 10^{13}$ and $1 \cdot 10^{16}$ protons $/ \mathrm{cm}^{2} 390$ days after the irradiation the number of released electrons with different energies was from 1.0 to 600 per second, respectively.

\subsection{Effect of irradiation on the contact properties of $4 \mathrm{H}$-SiC detectors}

In this chapter we will compare contact properties of the unirradiated and irradiated Schottky detectors. In Fig. 4 experimental $I-V$ curves of the investigated samples are presented. It can be seen that the unirradiated sample demonstrates clearly expressed rectifying behaviour characteristic of the nearly-ideal Schottky diode. It could be fitted well, by using Eqs. (1)-(4), as presented in Fig. 5. The following fitting parameters were used: potential barrier height $\Phi_{\mathrm{B}}=0.75 \mathrm{eV}$, ideality factor $n=1.05$, serial resistance of the sample volume $R_{\mathrm{S}}=35 \Omega$. While the coincidence of the forward branch is perfect, the reverse current exceeds that given by the model. This could be due to the leakage current flowing over the sample surface states.

With an increasing irradiation dose the rectifying behaviour becomes less expressed (Fig. 4). Whereas the samples irradiated with $1 \cdot 10^{13}$ and $1 \cdot 10^{14}$ protons $/ \mathrm{cm}^{2}$ still demonstrate asymmetry of the $I-V$ characteristics, 


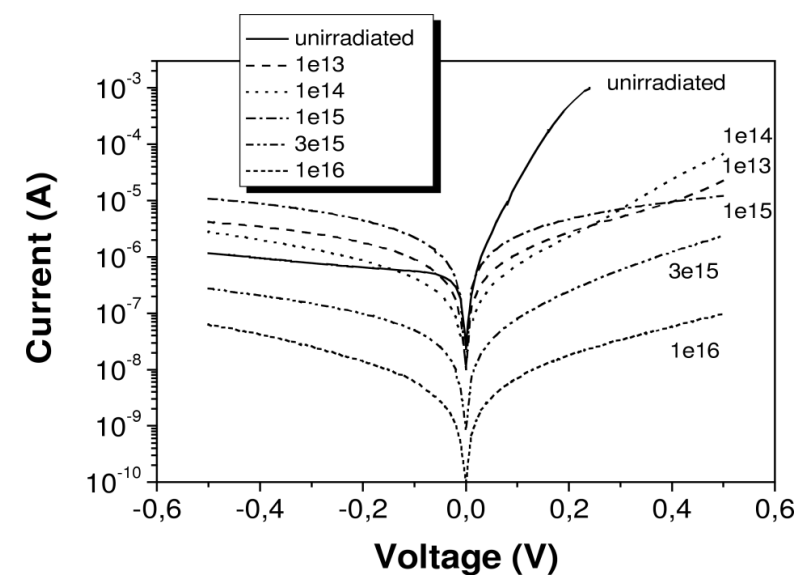

Fig. 4. Experimental $I-V$ curves of the investigated samples, depending on the proton-irradiation doses as indicated in the figure. Note that here and further the absolute current values are plotted.

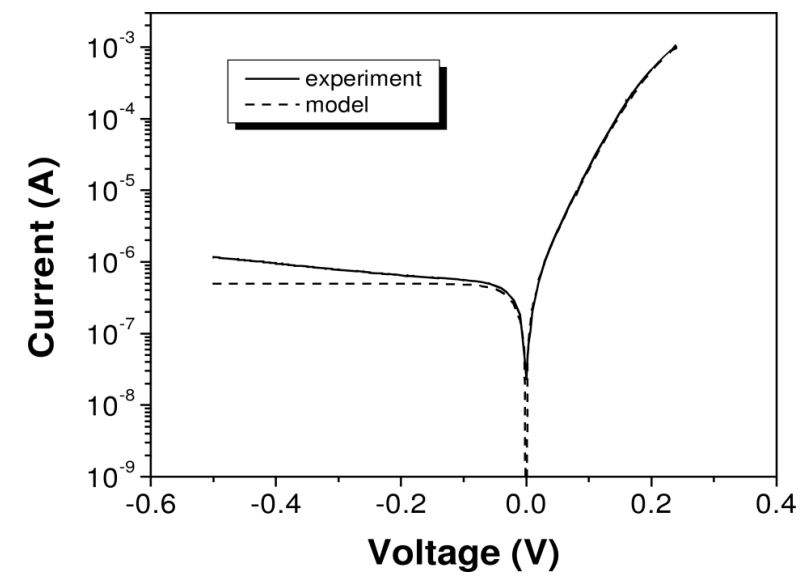

Fig. 5. Experimental $I-V$ curve and its modelling according to Eqs. (1)-(4) of the unirradiated detector.

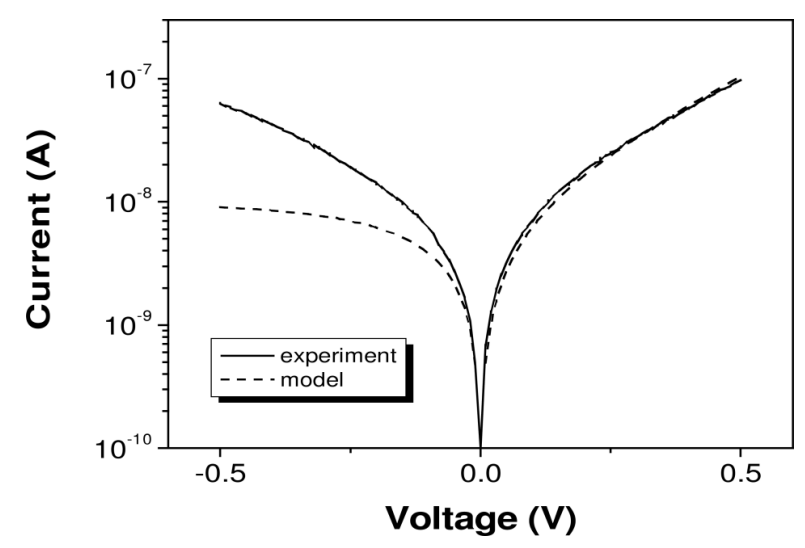

Fig. 6. Experimental $I-V$ curve and its modelling according to Eqs. (1)-(4) of the sample irradiated by $1 \cdot 10^{16}$ protons $/ \mathrm{cm}^{2}$.

at higher irradiation doses this asymmetry practically disappears, as presented in Fig. 6 for the sample irradiated by $1 \cdot 10^{16}$ protons $/ \mathrm{cm}^{2}$. Therefore the Schottky barrier model fails to describe such behaviour, as it can be seen in the same figure. Moreover, to fit the forward

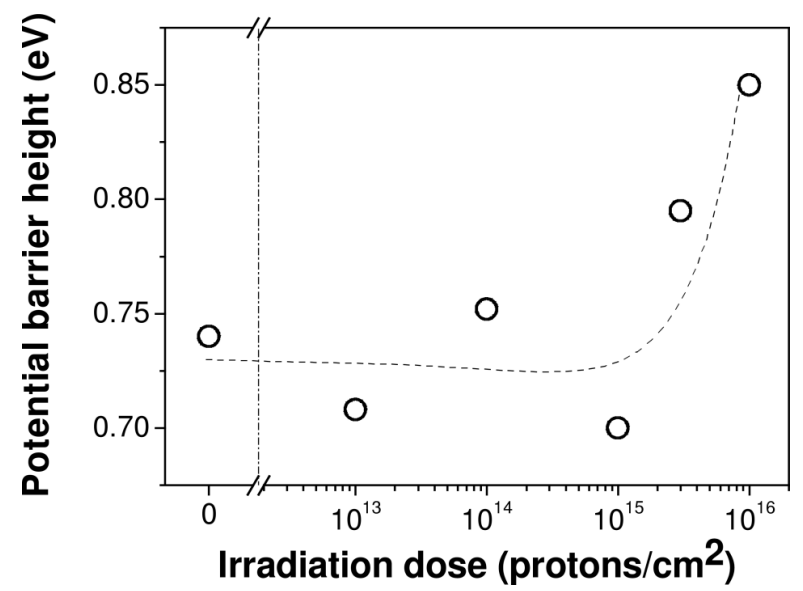

Fig. 7. Evaluated potential barrier heights in the investigated structures irradiated by different proton doses. Dashed line represents a third order polynomial approximation of the experimental points and serves as an eye-guide.

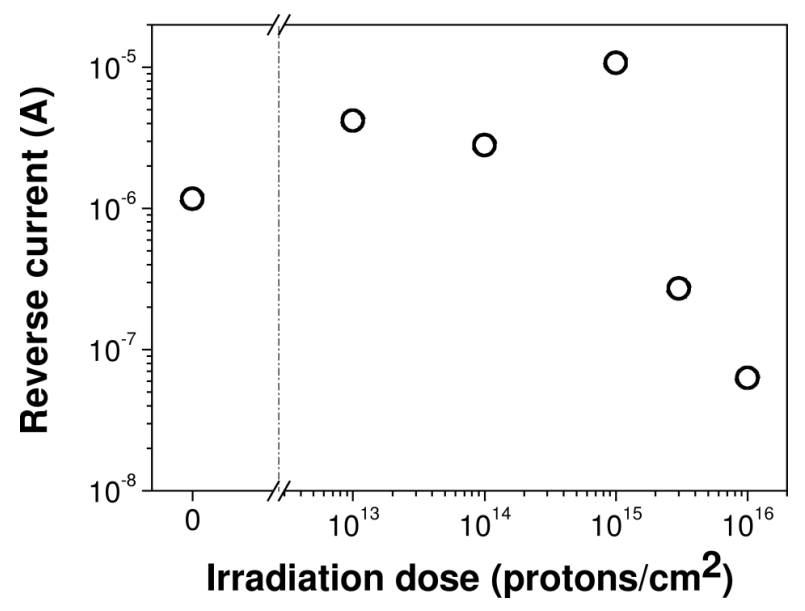

Fig. 8. Dependence of the reverse current measured at $-0.5 \mathrm{~V}$ voltage on the irradiation doses.

branch, an anomalously high ideality factor of up to 512 had to be chosen. This indicates that the ideality factor can only be treated as an effective value, which no longer reflects the real current flow mechanism in the irradiated structures. The best expressed changes upon irradiation in Fig. 4 are associated with the current drop over the samples. This drop is associated with the change of the potential barrier heights, as demonstrated in Fig. 7. Characteristically a slight decrease of the potential barrier height is seen at the lower irradiation doses of up to $1 \cdot 10^{15} \mathrm{~cm}^{-2}$, which also reflects itself as a slight maximum in the dependences of the reverse currents in Fig. 5. At the highest doses above $3 \cdot 10^{15} \mathrm{~cm}^{-2}$ a well-expressed growth of the potential barrier height takes place, causing the reverse current to drop in Fig. 8. These changes are followed by a growth of the sample volume resistivity of up to several thousand ohms. Nevertheless, such values are too low to 
limit current at low voltages, evidencing that the main mechanism limiting the current flow is associated with the existence of potential barriers.

From the described results it follows that even the lowest irradiation doses by high-energy protons of about $1 \cdot 10^{13} \mathrm{~cm}^{-2}$ significantly deteriorate the rectifying properties of $4 \mathrm{H}-\mathrm{SiC}$ detectors. Most probably this can be associated with the destruction of the contact region by high-energy particles. This leads to the appearance of the disordered structure, i.e., creation and redistribution of different potential barriers in the sample space. As usually, it should be followed by the percolation transport phenomena. A characteristic twofold modification of the device properties, depending on the dose, indicates competition of different processes. It can be assumed that at relatively low irradiation doses of up to $1 \cdot 10^{15} \mathrm{~cm}^{-2}$ a smaller number of defective regions are introduced in which electron transport through the contact region is enhanced because of the appearance of the highly conductive channels. This leads to a slight decrease of the effective potential barrier heights by about up to $\sim 0.05 \mathrm{eV}$, and, as a consequence, an increase of the reverse current by up to one order of magnitude. At this stage the crystalline structure of material is retained, and the introduced defects most probably appear as single conductive regions. As the irradiation doses grow above $3 \cdot 10^{15} \mathrm{~cm}^{-2}$, the material properties start to change rapidly, as can be seen from Figs. 4, 7, and 8. If one assumes that at the irradiation dose of $3 \cdot 10^{15}$ protons $/ \mathrm{cm}^{2}$ every high-energy proton introduces one defect in the crystal, then such a rough evaluation would result in the effective density of the defects of about $1.64 \cdot 10^{23} \mathrm{~cm}^{-3}$. At such large defect density the material cannot be treated as crystalline any longer. This means that the crystalline structure becomes completely destroyed, and the charge carrier transport is governed by a newly formed polycrystalline structure in which many different potential barriers appear. As these barriers can be differently oriented in space, the rectifying properties are significantly diminished. Nevertheless, in order to participate in electric transport, electrons have to overcome these barriers, therefore the nonlinearity of the $I-V$ characteristics is retained.

\section{Summary and conclusions}

We investigated the effect of irradiation by different doses of $24 \mathrm{GeV}$ protons of up to $10^{16} \mathrm{~cm}^{-2}$ upon the high-energy radiation detectors based on $4 \mathrm{H}-\mathrm{SiC}$. The detectors have been produced from $n$-type $4 \mathrm{H}-\mathrm{SiC}$ epilayers grown on the top of the $n^{+}$-type substrate. They were supplied with a nickel ohmic contact on the bottom surface and a gold Schottky contact on the top.

We had either measured directly or evaluated the numbers of different isotopes produced during the irradiation by protons. It was shown that in proton nuclear spallation reactions with carbon the $\mathrm{B}, \mathrm{Be}, \mathrm{Li}, \mathrm{He}$, and $\mathrm{H}$ isotopes are produced. Meanwhile, $\mathrm{Al}, \mathrm{Mg}, \mathrm{Na}$, $\mathrm{Ne}, \mathrm{F}, \mathrm{O}$, and $\mathrm{N}$ isotopes are produced in proton reactions with silicon. The total amount of stable isotopes formed in the samples irradiated by $10^{13}$ protons $/ \mathrm{cm}^{2}$ was $1.2 \cdot 10^{11} \mathrm{~cm}^{-2}$, and that produced in the samples irradiated by $10^{16}$ protons $/ \mathrm{cm}^{2}$ was $5.9 \cdot 10^{13}$.

Activities and numbers of ${ }^{7} \mathrm{Be}$ and ${ }^{22} \mathrm{Na}$ atoms produced in $\mathrm{SiC}$ detectors after the irradiation were measured experimentally, with good repeatability statistics. Activities of other radionuclides 390 days after the irradiation were calculated basing on this data. Activities of ${ }^{7} \mathrm{Be}$ and ${ }^{22} \mathrm{Na}$ were proportional to the total irradiation dose and ranged from 1.3 to $890 \mathrm{~Bq}$ and from 1.9 to $950 \mathrm{~Bq}$, respectively. In the samples irradiated with $1 \cdot 10^{13}$ and $1 \cdot 10^{16}$ protons $/ \mathrm{cm}^{2} 390$ days after the irradiation the number of radiated electrons with different energies was from 1.0 to 600 per second, respectively.

Contact properties of the devices were investigated by means of the $I-V$ characteristics. It was demonstrated that irradiation by high-energy protons deteriorate the rectifying properties of $4 \mathrm{H}-\mathrm{SiC}$ detectors. A twofold modification of device properties was identified, depending on the dose. At lower irradiation doses of up to $1 \cdot 10^{15}$ protons $/ \mathrm{cm}^{2}$, the slight decrease of the effective potential barrier heights from about $0.75 \mathrm{eV}$ down to $<0.7 \mathrm{eV}$ took place, that was accompanied by the increase of the reverse current of the devices by up to one order of magnitude. As the irradiation doses grew above $3 \cdot 10^{15} \mathrm{~cm}^{-2}$ the device properties used to change rapidly in the opposite direction. I. e., irradiation by up to $1 \cdot 10^{16}$ protons $/ \mathrm{cm}^{2}$ resulted in the increase of the potential barrier height up to $\sim 0.85 \mathrm{eV}$, followed by the drop of the reverse current by up to two orders of magnitude. The observed changes were attributed to the appearance of different potential barriers because of the destruction of crystalline structure of pristine material by the high-energy particle bombardment. This leads to the appearance of the disordered structure, i. e., creation and redistribution of different potential barriers in the sample space, that necessarily invokes the percolation transport phenomena. 


\section{References}

[1] Yu.A. Goldberg, M. Levinshtein, and S.L. Rumyantsev, Properties of Advanced Semiconductor Materials: GaN, AIN, InN, BN, SiC, SiGe, Chapter 5: Silicon Carbide (Wiley, New York, 2001) pp. 93-147.

[2] A. Castaldini, A. Cavallini, L. Rigutti, F. Nava, P.G. Fuochi, and P. Vanni, "Recovery" effect of electron induced damage in $4 \mathrm{H}-\mathrm{SiC}$ Schottky diodes, MRS Proc. 792, 611-616 (2004).

[3] A. Castaldini, A. Cavallini, L. Rigutti, and F. Nava, Low temperature annealing of electron irradiation induced defects in 4H-SiC, Appl. Phys. Lett. 85(17), 3780-3782 (2004).

[4] Z-Q. Fang, D.C. Look, A. Saxler, and W.C. Mitchel, Characterization of deep centers in bulk $n$-type 4H-SiC, Physica B 308-310, 706-709 (2001).

[5] D.V. Davydov, A.A. Lebedev, V.V. Kozlovski, N.S. Savkina, and A.M. Strel'chuk, DLTS study of defects in $6 \mathrm{H}-$ and $4 \mathrm{H}-\mathrm{SiC}$ created by proton irradiation, Physica B 308-310, 641-644 (2002).

[6] S. Maximenko, S. Soloviev, D. Cherednichenko, and T. Sudarshan, Electron-beam-induced current observed for dislocations in diffused $4 \mathrm{H}-\mathrm{SiC} \mathrm{P}-\mathrm{N}$ diodes, Appl. Phys. Lett. 84(9), 1576-1578 (2004).

[7] M. Tajima, M. Tanaka, and N. Hoshino, Characterization of SiC epitaxial wafers by photoluminescence under deep UV excitation, Mater. Sci. Forum 389393(1), 597-600 (2002).

[8] N.E. Korsunska, I. Tarasov, V. Kushnirenko, and S. Ostapenko, High-temperature photoluminescence spectroscopy in $p$-type SiC, Semicond. Sci. Technol. 19(7), 833-838 (2004).

[9] R. Weingärtner, P.J. Wellmann, M. Bickermann, D. Hofmann, T.L. Straubinger, and A. Winnacker, Determination of charge carrier concentration in $n$ - and $p$-doped $\mathrm{SiC}$ based on optical absorption measurements, Appl. Phys. Lett. 80(1), 70-72 (2002).

[10] R. Stibal, S. Müller, W. Jantz, G. Pozina, B. Magnusson, and A. Ellison, Nondestructive topographic resistivity evaluation of semiinsulating $\mathrm{SiC}$ substrates, Phys. Status Solidi C 0(3), 1013-1018 (2003).

[11] M. Mermoux, A. Crisci, and F. Baillet, Raman imaging analysis of SiC wafers, Mater. Sci. Forum 433-436, 353-356 (2003).

[12] S. Ostapenko, Yu.M. Suleimanov, I. Tarasov, S. Lulu, and S.E. Saddow, Thermally stimulated luminescence in full-size $4 \mathrm{H}-\mathrm{SiC}$ wafers, J. Phys. Cond. Matter 14(48), 13381-13386 (2002).

[13] Q. Li, A.Y. Polyakov, M. Skowronski, M.D. Roth, M.A. Fanton, and D.W. Snyder, Electrical nonuniformities and their impact on the electron mobility in semi-insulating SiC crystals, J. Appl. Phys. 96(1), 411-414 (2004).

[14] D.M. Martin, H. Kortegaard Nielsen, P. Leveque, A. Hallen, G. Alfieri, and B.G. Svensson, Bistable defect in mega-electron-volt proton implanted $4 \mathrm{H}$ silicon carbide, Appl. Phys. Lett. 84(10), 1704-1706 (2004).

[15] Y. Negoro, K. Katsumoto, T. Kimoto, and H. Matsunami, Electronic behaviors of high-dose phosphorus-ion implanted 4H-SiC (0001), J. Appl. Phys. 96(1), 224-227 (2004).

[16] L. Wang, J. Huang, X. Duo, Z. Song, Ch. Lin, C.M. Zetterling, and M. Östling, Investigation of damage behaviour and isolation effect of $n$-type $6 \mathrm{H}-\mathrm{SiC}$ by implantation of oxygen, J. Phys. D 33(12), 1551-1555 (2000).

[17] W. Cunningham, A. Gouldwell, G. Lamb, P. Roy, J. Scott, K. Mathieson, R. Bates, K.M. Smith, R. Cusco, I.M. Watson, M. Glaser, and M. Rahman, Probing bulk and surface damage in widegap semiconductors, J. Phys. D 34(18), 2748-2753 (2001).

[18] F. Nava, E. Vittone, P. Vanni, P.G. Fuochi, and C. Lanzieri, Radiation tolerance of epitaxial silicon carbide detectors for electrons and $\gamma$-rays, Nucl. Instrum. Methods A 514(1-3), 126-134 (2003).

[19] W. Cunningham, J. Melone, M. Horn, V. Kažukauskas, P. Roy, F. Doherty, M. Glaser, J. Vaitkus, and M. Rahman, Performance of irradiated bulk SiC detectors, Nucl. Instrum. Methods A 509(1), 127-131 (2003).

[20] R. Jasiulionis and H. Wershofen, A study of the vertical diffusion of the cosmogenic radionuclides, ${ }^{7} \mathrm{Be}$ and ${ }^{22} \mathrm{Na}$ in the atmosphere, J. Environmental Radioactivity 79(2), 157-169 (2005).

[21] R. Silberger and C.H. Tsao, Partial cross-section in high-energy nuclear reactions and astrophysical applications, Astrophys. J. Suppl. Ser. 25(220), 315-333 (1973).

[22] L. Silver, C.H. Tsao, R. Silberger, T. Kanai, and A.F. Barghouty, Total reaction and partial cross section calculations in proton-nucleus $\left(Z_{t} \leq 26\right)$ and nucleusnucleus reactions $\left(Z_{p}\right.$ and $\left.Z_{t} \leq 26\right)$, Phys. Rev. C 47(3), 1225-1236 (1993). 


\title{
DIDELĖS ENERGIJOS PROTONŲ POVEIKIS 4H-SiC JONIZUOJANČIOSIOS SPINDULIUOTĖS DETEKTORIAMS
}

\author{
V. Kažukauskas ${ }^{\text {a }}$, R. Jasiulionis ${ }^{\text {b }}$, V. Kalendra ${ }^{\text {a }}$, J.V. Vaitkus ${ }^{\text {a }}$ \\ ${ }^{a}$ Vilniaus universitetas, Vilnius, Lietuva \\ ${ }^{\mathrm{b}}$ Fizikos institutas, Vilnius, Lietuva
}

\section{Santrauka}

Tirta apšvitos didelès energijos protonais įtaka $4 \mathrm{H}-\mathrm{SiC}$ jonizuojančiosios spinduliuotès detektoriu savybèms. Šotkio (Schottky) detektoriai buvo pagaminti, naudojant $n$ laidumo tipo $4 \mathrm{H}-\mathrm{SiC}$ epitaksinius sluoksnius, užaugintus ant $n^{+}$tos pačios medžiagos padèklų. Šotkio kontaktas buvo suformuotas, darinio viršuje užgarinant aukso elektrodą, o apačioje buvo užgarintas ominis nikelio elektrodas. Detektorių elektrinès savybès buvo tiriamos, matuojant jų voltamperines priklausomybes. Naudojant žemo fono gama spektrometra, pastebėtas protonu branduolinèse reakcijose su Si ir $\mathrm{C}$ branduoliais susidariusiu ${ }^{7} \mathrm{Be}$ ir ${ }^{22} \mathrm{Na}$ spinduliavimas. Ivertinti tu ir kitų radionuklidų bei jų skilimo produktų kiekiai detektoriuose.

Parodyta, jog apšvita didelès energijos protonais esmingai keičia detektorių savybes. Visų pirma, žymiai mažèja diodo suge- bejjimas lyginti srovę, t. y., voltamperinès priklausomybès asimetrija. Kontakto parametru kitimas, didejjant apšvitos dozei, vyko dvejopai. Esant mažesnèms dozèms iki $1 \cdot 10^{15}$ protonu $/ \mathrm{cm}^{2}$, pastebètas potencialinio barjero aukščio sumažèjimas nuo maždaug $0,75 \mathrm{eV}$ iki $<0,7 \mathrm{eV}$, lydimas užtvarinès srovès stiprejjimo beveik viena eile. Tuo tarpu apšvitos dozei viršijus $3 \cdot 10^{15}$ protonu $/ \mathrm{cm}^{2}$, parametru pokytis yra priešingas ir žymiai labiau išreikštas. ApŠvitos dozei pasiekus $1 \cdot 10^{16}$ protonu $/ \mathrm{cm}^{2}$, potencialinio barjero aukštis padidejo iki $\sim 0,85 \mathrm{eV}$, o užtvarinè srovè atitinkamai sumažéjo maždaug dviem eilèmis. Pastebèti efektai aiškinami medžiagos kristalinès sandaros suardymu, apšaudant ją didelès energijos dalelèms, ir skirtingo aukščio bei orientacijos potencialinių barjerų susidarymu visame detektorių tūryje. 